\title{
APLIKASI PENYEMPROTAN PERASAN DAUN KAMBOJA (Plumeria acuminata) TERHADAP KEMATIAN LALAT RUMAH (Musca domestica)
}

\author{
Vina Yuliana, Yamtana, Abdul Hadi Kadarusno
}

\begin{abstract}
Jurusan Kesehatan Lingkungan (JKL) Politeknik Kesehatan Kemenkes Yogyakarta, Jl. Tatabumi 3, Banyuraden, Gamping, Sleman, Daerah Istimewa Yogyakarta 55293, email: yamtanakesmas@yahoo.co.id ; vinayulianay@yahoo.com
\end{abstract}

\begin{abstract}
Spraying application leaf squeeze kamboja (plumeria acuminata) to death fly house (musca domestica). Housefly (Musca domestica) is a vector for transmission of various types of mechanically transmitted diseases such as diarrhea, dysentery, cholera, typhoid, salmonellosis and viral gastrointestinal diseases. One of the control flies using environmentally friendly plant-based insecticides. Researchers used insecticides in the form of freshly squeezed vegetable leaf with frangipani (Plumeria acuminata). The objective was to knowing the influence of leaf squeeze spraying frangipani with a concentration of 40 percent, 50 percentand and 60 percent of the death house fly. This study uses experimental design With Post Test Only Control Group Design. The object of this study is the 480 flies were obtained from the TPS Market Tlagareja. This research was carried out by spraying the leaf squeeze frangipani at a concentration of $40 \%, 50 \%$ and $60 \%$. Counting the number of deaths house fly performed after 24 hours. The results of this research are there meaningful influence of sraying the frangipani leaf squeeze againts the death house flies and the value of sig 0,000 . Concentration of $40 \%, 50 \%$, and $60 \%$ respectively can be deadly flies an average of 5 tails, 10 tails and 15 tails. The most effective concentration was $60 \%$ obtained from the LSD test with significance level of 0.000 and Different Mean values (IJ) is the largest 10.00000. The conclusion is an effect spraying frangipani leaf squeeze with a concentration of $40 \%, 50 \%$, and $60 \%$ of the death house fly. The most effective concentration to kill flies is at $60 \%$, with an average mortality of flies 15 tails.
\end{abstract}

Keywords: frangipani leaf, house flies, insecticide plant.

\begin{abstract}
Abstrak: Aplikasi penyemprotan daun kamboja (Plumeria acuminata) terhadap kematian lalat rumah (Musca domestica). Lalat rumah (Musca domestica) berperan sebagai vektor mekanik bagi beberapa penyakit seperti diare, kolera, thipoid, salmonelosis dan penyakit yang berhubungan dengan pencernaan. Salah satu cara mengendalikan lalat yaitu dengan penggunaan insektisida yang ramah lingkungan. Peneliti menggunakan insektisida yang berasal dari bagian tumbuhan yaitu berupa perasan daun kamboja (Plumeria acuminata) segar. Tujuan penelitian ini adalah untuk mengetahui pengaruh dari penyemprotan perasan daun kamboja pada konsentrasi 40 persen, 50 persen dan 60 persen terhadap kematian lalat rumah. Obyek penelitian menggunakan 480 ekor lalat rumah pada TPS Pasar Tegalreja, lalat tersebut disemprot menggunakan perasan daun kamboja pada konsentrasi yang telah ditetapkan. Lalat yang mati dihitung setelah 24 jam. Hasil penelitian menunjukkan terdapat pengaruh konsentrasi perasan daun kamboja pada kematian lalat rumah dengan signifikansi 0,000. Konsentrasi perasan daun kamboja 40 persen, 50 persen dan 60 persen mampu membunuh lalat rumah dengan rata-rata kematian sebesar 5, 10 dan 15 ekor. Konsentrasi yang paling efektif berdasarkan uji LSD adalah 60 persen dengan tingkat signifikansi sebesar 0,000.
\end{abstract}

Kata kunci : Perasan daun, Lalat rumah, insektisida alami 


\section{PENDAHULUAN}

Kesehatan masyarakat merupakan salah satu modal pokok dalam rangka pertumbuhan dan kehidupan bangsa. Salah satu upaya peningkatan derajat kesehatan adalah melalui perbaikan kesehatan lingkungan. Upaya kesehatan lingkungan ditujukan untuk mewujudkan kualitas lingkungan yang sehat, baik fisik, kimia, biologi, maupun sosial yang memungkinkan setiap orang mencapai derajat kesehatan yang setinggi-tingginya. Lingkungan sehat mencakup lingkungan permukiman, tempat kerja, tempat rekreasi, serta tempat dan fasilitas umum ${ }^{1)}$. Salah satu unsur yang dapat menimbulkan gangguan kesehatan yaitu binatang pembawa penyakit.

Lalat adalah vektor yang termasuk dalam filum Arthropoda dan ordo Diptera yang dapat bertindak sebagai binatang pengganggu. Bagi dunia kesehatan, Arthropoda termasuk dalam kelompok vektor yang berbahaya dan dapat merugikan kehidupan manusia ${ }^{2}$. Terdapat banyak jenis lalat tetapi yang paling banyak merugikan manusia adalah jenis lalat rumah (Musca domestica). Lalat rumah merupakan salah satu vektor utama penyebaran berbagai jenis penyakit yang ditularkan secara mekanis, seperti: diare, disentri, kolera, tifus, salmonelosis dan virus penyakit saluran pencernaan ${ }^{3)}$.

Salah satu tempat umum yang paling banyak dikunjungi masyarakat adalah pasar. Aktifitas penjual dan pembeli pada umumnya membuang sampah, yang dapat menjadi tempat berkembangbiak serta sarana dari bermacam-macam vektor penularan penyakit salah satunya yaitu lalat. Pasar Tlagareja terletak di Kecamatan Gamping, Kabupaten Sleman, Daerah Istimewa Yogyakarta. Jenis sampah berupa sampah padat, seperti: sisa-sisa makanan, plastik, potongan sayur-mayur, buah, daging, ikan, dan kertas.

Informasi yang diperoleh dari pengelola Pasar Tlagareja, bahwa pembuangan sampah ke Tempat Pembuangan Akhir (TPA) Piyungan dengan menggunakan truk pengangkut sampah dari Dinas Pekerjaan Umum di
Kabupaten Sleman, dilakukan seminggu 2 kali pada hari Selasa dan Jumat. Sehingga sampah menumpuk, serta mempercepat pertumbuhan dan perkembangbiakan lalat. Volume sampah dalam sekali pengangkutan kurang lebih 10 meter kubik. Di Pasar Tlagareja juga belum dilakukan upaya pengendalian lalat. Berdasarkan survei pendahuluan dan wawancara yang dilakukan tanggal 10 Februari 2014, didapatkan bahwa $100 \%$ pedagang yang berada di dekat TPS merasa tidak nyaman dengan lalat yang ada. Pengukuran kepadatan lalat di TPS Pasar Tlagareja diperoleh sebesar 35 ekor/block grill. Hasil yang diperoleh berada ditingkatan interpretasi yang paling tinggi yaitu di atas 20 ekor/block grill. Kepadatannya termasuk dalam populasi sangat padat. Oleh karena itu perlu dilakukan pengamanan terhadap tempat-tempat berkembangbiaknya lalat serta tindakan pengendaliannya ${ }^{4)}$.

Salah satu cara pengendalian lalat dengan menggunakan insektisida. Penggunaan insektisida kimia menyebabkan pencemaran lingkungan, oleh karena itu sebagai alternatif pengendalian lalat yang ramah lingkungan dengan menggunakan insektisida nabati yang terbuat dari tumbuhan ${ }^{5}$. Ada beberapa jenis tumbuhan yang dapat dimanfaatkan sebagai insektisida nabati. Dalam hal ini peneliti berinisiatif untuk memanfaatkan daun kamboja (Plumeria acuminata) sebagai insektisida nabati dalam bentuk perasan. Membuat perasan adalah cara yang relatif sederhana dan mudah untuk dilakukan.

Beberapa kandungan kimia yang ada dalam daun kamboja adalah saponin, alkaloid, flavanoid, dan polifenol6). Saponin adalah senyawa yang rasanya pahit dan bersifat racun untuk binatang kecil. Alkaloid adalah senyawa kimia yang dapat melumpuhkan dan mematikan lalat rumah. Flavanoid menimbulkan kelayuan pada saraf dan kerusakan spirakel pada serangga ${ }^{7)}$.

Menurut penelitian Crhisjanie (2012), perasan daun pandan wangi (Pandanus amarylliforus roxb) berpengaruh dalam membunuh lalat. 
Konsentrasi yang paling banyak membunuh lalat adalah 20\%. Mengacu pada penelitian tersebut peneliti memilih konsentrasi perasan daun kamboja (Plumeria acuminata) sebesar 20\%, 30\%, $40 \%$. Karena terdapat kesamaan kandungan bahan aktif antara daun pandan wangi dengan perasan daun kamboja. Daun pandan wangi mengandung alkaloid, saponin, flavanoid, tanin, dan polifenol. Sedangkan kandungan bahan aktif yang terdapat pada daun kamboja adalah alkaloid, flavonoid, saponin, dan polifenol.

Uji pendahuluan yang dilakukan pada tanggal 4 Maret 2014, dengan daun Kamboja 130 gram yang dijadikan perasan, diambil $20 \mathrm{ml}$ kemudian ditambah air hingga $100 \mathrm{ml} \mathrm{(20 \% )} \mathrm{dan} 40$ $\mathrm{ml}$ ditambah air hingga $100 \mathrm{ml}$ (40\%). Kematian lalat setelah di holding selama 24 jam pada konsentrasi $20 \%$ adalah 3 ekor lalat dari 20 lalat uji, sedangkan pada konsentrasi $40 \%$ adalah 9 ekor dari 20 lalat uji.

Berdasarkan penjelasan dan uji pendahuluan di atas, maka rumusan masalah penelitian ini adalah apakah ada pengaruh penyemprotan perasan daun Kamboja (Plumeria acuminata) dengan konsentrasi 40\%, 50\%, dan 60\% terhadap kematian lalat rumah (Musca domestica)?

Tujuan penelitian ini adalah untuk mengetahui pengaruh penyemprotan perasan daun Kamboja (Plumeria acuminata) dengan konsentrasi 40\%, $50 \%$, dan $60 \%$ terhadap kematian lalat rumah. Adapun manfaat dari penelitian ini yaitu sebagai tambahan informasi dalam ilmu-ilmu yang berhubungan dengan pengendalian vektor terutama tentang penggunaan insektisida nabati.

\section{BAHAN DAN CARA PENELITIAN}

Jenis penelitian ini merupakan eksperimen dengan menggunakan Post Test Only With Control Group Design. Obyek dalam penelitian ini adalah daun Kamboja yang dipetik pada daun ruas ke 4-6 dari pucuk daun yang masih segar dan tidak rusak. Sampel lalat rumah (Musca domestica) dalam penelitian ini berjumlah
480 ekor untuk 6 kali pengulangan. Setiap perlakuan menggunakan lalat sebanyak 20 ekor. Perlakuan pada penelitian ini adalah penyemprotan perasan daun Kamboja (Plumeria acuminata) terhadap lalat rumah dengan konsentrasi perasan $40 \%$, 50\%, dan $60 \%$ serta air sebagai kontrol (0\%). Penelitian ini dilakukan di Laboratorium Vektor, Jurusan Kesehatan Lingkungan, Politeknik Kesehatan Kemenkes Yogyakarta. Cara menentukan lalat rumah yang akan diberi perlakuan yaitu dengan mengelompokkan lalat rumah yang besarnya hampir sama.

Bahan dan alat yang digunakan dalam penelitian ini meliputi daun kamboja (Plumeria acuminata), lalat rumah (Musca domestica), air aqua, air bersih, sabun cuci cair, susu kental manis, gula pasir, glass chamber ukuran $70 \times 70 \times 70 \mathrm{~cm}$, alat semprot merk Top Gun Multipurpose Hand Sprayer, blender merk Philips, Neraca Ohaus, gelas ukur, kain blacu, kapas, kain strimin aspirator, paper cup, sangkar lalat, kanebo, pengukur waktu (jam).

Variabel bebas dalam penelitian ini adalah berbagai konsentrasi perasan daun kamboja (Plumeria acuminata). Variabel terikat dari penelitian ini adalah kematian lalat rumah (Musca domestica). Adapun variabel pengganggu dalam penelitian ini adalah frekuensi penyemprotan, volume penyemprotan, alat semprot jenis lalat, dan umur lalat.

Data penelitian dianalisis secara deskriptif dan inferensial menggunakan program komputer SPSS for windows version 20. Analisis data secara deskriptif disajikan dalam bentuk tabel. Sedangkan analisis data inferensial dengan normalitas data menggunakan uji Kolmogorov-Smirnov. Kemudian dilanjutkan uji parametrik One Way Anova, dengan tingkat signifikasi $\quad \alpha<0,05$. Selanjutnya data diuji menggunakan $L S D$ untuk mengetahui konsentrasi perasan daun kamboja yang paling efektif, ditunjukkan dengan tanda asterik (*) pada kolom Mean Different (I-J) dan pada kolom sig. dengan nilai sig. $<\alpha=0,05$ serta nilai Mean Different (I-J) yang paling besar. 


\section{HASIL DAN PEMBAHASAN}

Data jumlah kematian lalat rumah (Musca domestica) kelompok kontrol setelah 1 jam dan holding 24 jam dapat dilihat pada Tabel 1 berikut ini.

Tabel 1. Jumlah lalat rumah yang mati pada kelompok kontrol

\begin{tabular}{cccc}
\hline $\begin{array}{c}\text { Peng- } \\
\text { ulanga } \\
\mathrm{n}\end{array}$ & $\begin{array}{c}\text { Jml } \\
\text { lalat } \\
\text { uji }\end{array}$ & $\begin{array}{c}\text { Jml lalat } \\
\text { yang } \\
\text { mati }\end{array}$ & $\begin{array}{c}\text { Persentase } \\
(\%)\end{array}$ \\
\hline 1 & 20 & 0 & 0 \\
\hline 2 & 20 & 0 & 0 \\
\hline 3 & 20 & 0 & 0 \\
\hline 4 & 20 & 0 & 0 \\
\hline 5 & 20 & 0 & 0 \\
\hline 6 & 20 & 0 & 0 \\
\hline Jml & 120 & 0 & 0 \\
\hline $\begin{array}{c}\text { Rata- } \\
\text { rata }\end{array}$ & 20 & 0 & 0 \\
\hline
\end{tabular}

Berdasarkan Tabel 1 kematian lalat rumah pada kelompok kontrol sebesar $0 \%$, maka tidak perlu dikoreksi dengan rumus Abbot.

Data jumlah kematian lalat rumah pada kelompok perlakuan dengan konsentrasi $40 \%$ setelah 1 jam dan holding 24 jam dapat dilihat pada tabel di bawah ini.

Tabel 2. Jumlah lalat rumah yang mati setelah penyemprotan dengan perasan daun kamboja pada konsentrasi $40 \%$

\begin{tabular}{cccc}
\hline $\begin{array}{c}\text { Peng- } \\
\text { ulanga } \\
\text { n }\end{array}$ & $\begin{array}{c}\text { Jml } \\
\text { lalat } \\
\text { uji }\end{array}$ & $\begin{array}{c}\text { Jml lalat } \\
\text { yang } \\
\text { mati }\end{array}$ & $\begin{array}{c}\text { Persentase } \\
(\%)\end{array}$ \\
\hline 1 & 20 & 7 & 35 \\
\hline 2 & 20 & 5 & 25 \\
\hline 3 & 20 & 5 & 25 \\
\hline 4 & 20 & 4 & 20 \\
\hline 5 & 20 & 6 & 30 \\
\hline 6 & 20 & 5 & 25 \\
\hline Jml & 120 & 32 & 160 \\
\hline $\begin{array}{c}\text { Rata- } \\
\text { rata }\end{array}$ & 20 & 5,33 & 26,66 \\
\hline \multicolumn{3}{c}{ Berdasarkan Tabel 2 kematian lalat }
\end{tabular}
rumah pada perlakuan dengan konsentrasi $40 \%$ yang paling tinggi pada pengulangan ke 1 sebesar $35 \%$ atau 7 ekor, dan paling rendah pada pengulangan ke 4 sebesar $20 \%$ atau 4 ekor. Rata-rata kematian lalat rumah dari 6 kali pengulangan sebesar $26,66 \%$.

Data jumlah kematian lalat rumah (Musca domestica) pada kelompok perlakuan dengan konsentrasi $50 \%$ setelah 1 jam dan holding selama 24 jam dapat dilihat pada tabel di bawah ini.

Tabel 3. Jumlah lalat rumah yang mati setelah penyemprotan dengan perasan daun kamboja pada konsentrasi $50 \%$

\begin{tabular}{cccc}
\hline $\begin{array}{c}\text { Peng- } \\
\text { ulanga } \\
\mathrm{n}\end{array}$ & $\begin{array}{c}\text { Jml } \\
\text { lalat } \\
\text { uji }\end{array}$ & $\begin{array}{c}\text { Jml } \\
\text { lalat } \\
\text { yang } \\
\text { mati }\end{array}$ & $\begin{array}{c}\text { Persentase } \\
(\%)\end{array}$ \\
\hline 1 & 20 & 11 & 55 \\
\hline 2 & 20 & 9 & 45 \\
\hline 3 & 20 & 10 & 50 \\
\hline 4 & 20 & 8 & 40 \\
\hline 5 & 20 & 11 & 55 \\
\hline 6 & 20 & 12 & 60 \\
\hline Jumlah & 120 & 61 & 305 \\
\hline $\begin{array}{c}\text { Rata- } \\
\text { rata }\end{array}$ & 20 & 10,16 & 50,83 \\
\hline
\end{tabular}

Berdasarkan Tabel 3 di atas, dapat disimpulkan bahwa kematian lalat rumah perlakuan dengan konsentrasi $50 \%$ yang paling tinggi pada pengulangan ke 6 sebesar $60 \%$ atau 12 ekor, dan yang paling rendah pada pengulangan ke 4 sebesar $40 \%$ atau 8 ekor. Rata-rata kematian lalat rumah pada perlakuan dengan konsentrasi $50 \%$ dari 6 kali pengulangan yaitu sebesar $50,83 \%$ atau 10 ekor.

Data dari jumlah kematian lalat rumah (Musca domestica) pada kelompok perlakuan penyemprotan perasan daun kamboja (Plumeria acuminata) dengan konsentrasi $60 \%$ setelah 1 jam dan holding selama 24 jam dapat dilihat pada Tabel 4 berikut ini. 
Tabel 4. Jumlah lalat rumah yang mati setelah penyemprotan dengan perasan daun kamboja pada konsentrasi $60 \%$

\begin{tabular}{cccc}
\hline $\begin{array}{c}\text { Peng- } \\
\text { ulangan }\end{array}$ & $\begin{array}{c}\text { Jml } \\
\text { lalat } \\
\text { uji }\end{array}$ & $\begin{array}{c}\text { Jml } \\
\text { lalat } \\
\text { yang } \\
\text { mati }\end{array}$ & $\begin{array}{c}\text { Persentase } \\
(\%)\end{array}$ \\
\hline 1 & 20 & 14 & 70 \\
\hline 2 & 20 & 16 & 80 \\
\hline 3 & 20 & 17 & 85 \\
\hline 4 & 20 & 15 & 75 \\
\hline 5 & 20 & 14 & 70 \\
\hline 6 & 20 & 16 & 80 \\
\hline Jml & 120 & 92 & 460 \\
\hline $\begin{array}{c}\text { Rata- } \\
\text { rata }\end{array}$ & 20 & 15,33 & 76,66 \\
\hline
\end{tabular}

Berdasarkan Tabel 4 kematian lalat rumah pada perlakuan dengan konsentrasi $60 \%$ yang paling tinggi pada pengulangan 3 sebesar $85 \%$ dan paling rendah pada pengulangan 1 dan 5 sebesar $70 \%$. Rata-rata kematian lalat rumah dari 6 kali pengulangan sebesar $76,66 \%$.

Berdasarkan Tabel 1, 2, 3, dan 4 dapat diketahui rata-rata kematian lalat rumah akibat penyemprotan perasan daun kamboja dengan konsentrasi $40 \%$, $50 \%, 60 \%$ dan kontrol (0\%). Persentase kematian lalat rumah dapat dilihat pada gambar berikut ini.

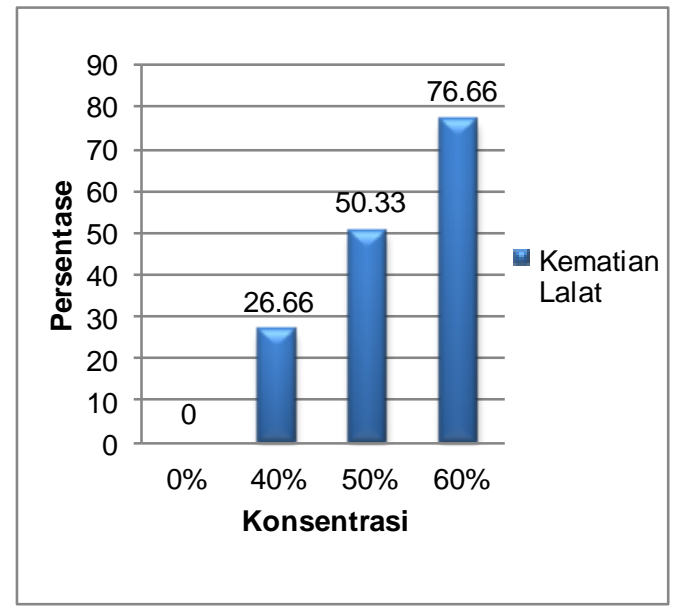

Gambar 1. Persentase jumlah lalat rumah yang mati berdasarkan variasi konsentrasi perasan daun kamboja
Berdasarkan grafik di atas menunjukkan bahwa persentase kematian lalat pada perlakuan dengan konsentrasi $40 \%$ sebesar $26,66 \%$, persentase kematian lalat pada perlakuan dengan konsentrasi $50 \%$ sebesar $50,33 \%$, dan persentase kematian lalat pada perlakuan dengan konsentrasi $60 \%$ sebesar 76,66\%. Hal ini menujukkan bahwa konsentrasi yang paling banyak mematikan lalat yaitu konsentrasi $60 \%$.

Tabel 5. Jumlah lalat rumah yang mati setelah 1 jam penyemprotan dengan perasan daun kamboja dan holding 24 jam

\begin{tabular}{ccccc}
\hline \multirow{2}{*}{$\begin{array}{c}\text { Peng- } \\
\text { ulanga } \\
\mathrm{n}\end{array}$} & \multicolumn{4}{c}{ Kematian lalat pada } \\
\cline { 2 - 5 } & $\begin{array}{c}\text { Kontro } \\
\mathrm{l}(0 \%)\end{array}$ & $\begin{array}{c}40 \\
\%\end{array}$ & 50 & $60 \%$ \\
\hline 1 & 0 & 7 & 11 & 14 \\
\hline 2 & 0 & 5 & 9 & 16 \\
\hline 3 & 0 & 5 & 10 & 17 \\
\hline 4 & 0 & 4 & 8 & 15 \\
\hline 5 & 0 & 6 & 11 & 14 \\
\hline 6 & 0 & 5 & 12 & 16 \\
\hline Jumlah & 0 & 32 & 61 & 92 \\
\hline Rata- & 0 & 5,3 & 10,1 & 15,3 \\
rata & & 3 & 6 & 3 \\
\hline
\end{tabular}

Data pada Tabel 5 di atas dilakukan analisis inferensial. Berdasarkan hasil perhitungan dengan uji One Way Anova terhadap variasi pemberian konsentrasi perasan daun kamboja (Plumeria acuminata) perlakuan dengan taraf signifikan 5\% diketahui bahwa nilai sig. = 0,000 yang berarti sig. $<0,05$ dengan demikian ada pengaruh yang bermakna penyemprotan perasan daun kamboja terhadap kematian lalat rumah. Uji LSD untuk mengetahui konsentrasi penyemprotan perasan daun kamboja (Plumeria acuminata) yang paling efektif terhadap kematian lalat rumah (Musca domestica). Perbedaan antar perlakuan dapat dilihat pada tabel hasil uji LSD yaitu dengan melihat tanda asterik $\left({ }^{*}\right)$ yang ada pada kolom Mean Different (I-J) dan pada kolom sig. dengan nilai sig. $<\alpha=0,05$ serta nilai Mean Different (I-J) yang paling besar. 
Lalat rumah berperan besar dalam penyebaran penyakit khususnya yang dapat ditularkan melalui makanan, peralatan, penjamah, dan tempat makanan tersebut berada sehingga perlu mendapat pengawasan yang cermat agar tidak mengganggu kehidupan dan kesehatan manusia.

Pengendalian yang dilakukan pada lalat rumah (Musca domestica) dalam penelitian ini secara kimiawi, yaitu menggunakan insektisida nabati berupa perasan daun kamboja (Plumeria acuminata). Target penyemprotan perasan daun kamboja yaitu lalat rumah dewasa, sehingga lalat yang bertelur berkurang dan populasi larva/pupa menurun ${ }^{8)}$.

Konsentrasi perasan daun kamboja yang digunakan yaitu $40 \%, 50 \%$, $60 \%$ dan kontrol (0\%). Hasil dari 6 kali pengulangan menunjukkan bahwa ratarata jumlah kematian lalat rumah (Musca domestica) konsentrasi $40 \%$ sebesar 5 ekor, konsentrasi $50 \%$ sebesar 10 ekor dan konsentrasi $60 \%$ sebesar 15 ekor. Sedangkan pada kelompok kontrol tidak terjadi kematian atau persentase kematian 0\% maka tidak dikoreksi dengan rumus Abbot. Hasil tersebut menunjukkan bahwa jumlah kematian lalat rumah yang terbanyak pada konsentrasi $60 \%$ sedangkan jumlah kematian lalat rumah (Musca domestica) yang paling sedikit pada konsentrasi $40 \%$. Jumlah kematian lalat rumah (Musca domestica) pada kelompok perlakuan dari ketiga konsentrasi menunjukkan bahwa semakin tinggi konsentrasi perasan daun kamboja (Plumeria acuminata) yang disemprotkan, maka semakin tinggi pula jumlah kematian lalatnya. Hal ini disebabkan karena semakin tinggi konsentrasi perasan daun kamboja maka akan semakin banyak bahan aktif yang terkandung di dalamnya.

Penelitian ini sejalan dengan penelitian yang dilakukan Sari (2013), meneliti uji efektifitas beberapa insektisida nabati untuk mengendalikan ulat grayak (Spodoptera litura F.) (Lepidoptera: Noctuidae) di laboratorium, dimana dilakukan 2 kali pengulangan yang diberi konsentrasi ekstrak daun kamboja 250 gr/liter (P5) dan 500 gr/liter (P6). Persentase mortalitas larva ulat grayak pada P5 sebesar 50\% sedangkan pada P6 sebesar 75\%. Hal ini menunjukkan bahwa semakin besar konsentrasi, maka zat aktif yang terdapat dalam ekstrak daun kamboja juga semakin besar, sehingga mortalitasnya pun semakin meningkat ${ }^{9}$.

Hasil dari uji normalitas data Kolmogorof-Smirnov, dari ketiga konsentrasi memiliki nilai Asym Sig. (2tailed) $>0,05$ yang berarti bahwa data yang diperoleh berdistribusi normal sehingga dapat dilanjutkan dengan uji One Way Anova. Hasil uji One Way Anova didapatkan nilai taraf signifikan kelompok perlakuan dari berbagai konsentrasi adalah $<0,05$. Hal ini menunjukkan bahwa adanya pengaruh penyemprotan perasan daun kamboja (Plumeria acuminata) terhadap kematian lalat rumah, dengan demikian penyemprotan perasan daun kamboja mampu memberikan hasil yang signifikan terhadap kematian lalat rumah (Musca domestica). Kematian lalat rumah kelompok perlakuan mengalami kenaikan yang sejalan dengan kenaikan penambahan konsentrasi perasan daun kamboja.

Berdasarkan hasil uji Post Hoc Test, di antara konsentrasi 40\%, 50\%, dan 60\%, konsentrasi yang paling efektif untuk mematikan lalat rumah (Musca domestica) adalah konsentrasi $60 \%$ dengan beda rata-rata tertinggi yaitu sebesar 10,0000 dan berdasarkan analisis deskriptif konsentrasi 60\% mampu mematikan lalat rumah (Musca domestica) sebesar 76,66\% atau 15 ekor lalat.

Lalat rumah yang mati pada semua perlakuan ini terjadi karena bahan yang disemprotkan. Bahan yang disemprotkan berupa perasan daun kamboja (Plumeria acuminata) yang terkandung bahan aktif di dalamnya. Kandungan bahan aktif perasan daun kamboja (Plumeria acuminata) yang mendominasi adalah kandungan flavanoid, alkaloid, saponin dan polifenol.6) Insektisida nabati yang berupa perasan daun kamboja merupakan racun kontak dengan masuk ke dalam tubuh lalat rumah secara kontak langsung. 
Flavanoid masuk ke dalam tubuh serangga melalui sistem pernafasan berupa spirakel yang terdapat di permukaan tubuh dan menimbulkan kelayuan pada saraf, serta kerusakan pada spirakel akibatnya tidak dapat bernafas dan akhirnya mengalami kematian. Alkaloid memberikan rangsangan yang keras bagi hewan target, mempengaruhi secara langsung kerja dari otot-otot serangga sehingga membutuhkan oksigen yang banyak kemudian diikuti kelumpuhan dan menyebabkan kematian. Saponin masuk melalui dinding tubuh serangga dan bersifat racun terhadap serangga7). Polifenol menyebabkan denaturasi protein penyusunan dinding sel sehingga sel akan mengalami gangguan metabolisme dan fisiologis sehingga menyebabkan kerusakan sel.

Penyemprotan perasan daun kamboja terhadap kematian lalat rumah dilakukan dengan cara residual spraying dan mempunyai efek knock down, yang berarti setelah terpapar perasan daun kamboja maka lalat akan mengalami kematian dalam beberapa waktu.

Pemakaian insektisida nabati disukai karena pada umumnya mempunyai daya racun yang kuat terhadap serangga tetapi tidak berbahaya bagi lingkungan. Insektisida nabati ini digunakan untuk pengendalian lalat sehingga dapat menurunkan penyakit yang berada di lingkungan. Keunggulan insektisida nabati perasan daun kamboja yaitu murah, mudah dibuat dan relatif aman terhadap lingkungan, tetapi juga mempunyai kelemahan yaitu daya kerjanya relatif lambat, tidak tahan terhadap paparan sinar matahari, kurang praktis, tidak tahan disimpan, dan kadangkadang harus disemprotkan berulangulang10).

Berdasarkan kelemahan tersebut maka setelah pembuatan perasan daun kamboja, penyemprotan terhadap lalat rumah dilakukan sesegera mungkin karena bahan aktif yang terkandung di dalamnya mudah menguap, jika disimpan dalam waktu yang lama. Berbeda dengan insektisida nabati dalam bentuk ekstrak yang lebih tahan untuk disimpan dalam waktu yang lama.

Cara membuat perasan daun kamboja untuk konsentrasi yang paling efektif (60\%) yaitu memetik daun kamboja yang masih segar, tidak rusak dan pada daun ruas ke 4-6 dari pucuk daun, karena daun pada posisi tersebut memiliki kandungan zat aktif yang paling baik. Selanjutnya dicuci dengan air mengalir dan ditiriskan sampai kering. Menimbang 150 gram daun kamboja kemudian dipotong-potong dengan ukuran kurang lebih $0,5 \mathrm{~cm}$, diblender sampai halus dan diperas menggunakan kain blacu. Diambil $60 \mathrm{ml}$ perasan daun kamboja dilarutkan dalam air sampai volume $100 \mathrm{ml}$, kemudian dimasukkan ke dalam alat penyemprot (hand sprayer) kemudian digojog hingga homogen. Insektisida nabati perasan daun kamboja siap untuk diaplikasikan.

Penelitian yang mengenai pengaruh penyemprotan perasan daun kamboja terhadap kematian lalat rumah telah memberikan hasil bahwa perasan daun kamboja dapat digunakan sebagai insektisida nabati untuk mematikan lalat rumah. Selain itu penggunaan perasan daun kamboja juga ramah lingkungan.

\section{KESIMPULAN DAN SARAN}

Ada pengaruh penyemprotan perasan daun kamboja (Plumeria acuminata) konsentrasi 40\%, konsentrasi $50 \%$ dan konsentrasi $60 \%$ terhadap kematian lalat rumah (Musca domestica) dengan jumlah rata-rata 5 ekor atau 26,66\%, 10 ekor atau 50,33\%, dan 15 ekor atau $76,66 \%$. Konsentrasi penyemprotan perasan daun kamboja (Plumeria acuminata) terhadap kematian lalat rumah yang paling efektif yaitu konsentrasi $60 \%$ dengan rata-rata kematian lalat rumah sebanyak 15 ekor atau $76,66 \%$.

\section{UCAPAN TERIMA KASIH}

Pada kesempatan ini penulis mengucapkan terima kasih kepada:

1. Bapak Seno Wibowo, SST, dan Samidi, SST, teknisi laboratorium Jurusan 
Kesehatan Lingkungan, Politeknik Kesehatan Kemenkes Yogyakarta, yang telah membantu pelaksanaan penelitian ini.

2. Kepala Pasar Tlagareja, Gamping Sleman, DIY yang telah memberi ijin penangkapan lalat di pasar tersebut.

\section{KEPUSTAKAAN}

1. Depkes RI. 2009. Undang-Undang RI No 36 Tahun 2009 tentang Kesehatan. Jakarta: CV. Novindo Pustaka Mandiri.

2. Suyono dan Budiman. 2010. Ilmu Kesehatan Masyarakat Dalam Konteks Kesehatan Lingkungan. EGC: Jakarta.

3. Winarno, F.G. 2006. Hama Gudang dan Teknik Pemberantasannya. Bogor: MBRIO PRESS, Edisi Revisi.

4. Depkes RI. 2008. Pedoman Pengendalian Lalat di Pelabuhan. Jakarta: Dirjen Pengendalian Penyakit dan Penyehatan Lingkungan.

5. Yudiarti, Turrini. 2010. Cara Praktis \& Ekonomis Mengatasi Hama dan Penyakit Tanaman Pangan dan Hortikultura. Yogyakarta: Graha Ilmu.

6. Syamsuhidayat, Sri Sugati. 1991. Inventaris Tanaman Obat Indonesia. Penelitian dan Pengembangan Kesehatan. Depkes RI.
7. Pitojo, Setijo dan Zumiati. 2003. Tanaman Bumbu dan Pewarna Nabati. Semarang: Aneka Ilmu.

8. Balfas, Rodiah. Status Lalat Rimpang Pada Tanaman Jahe dan Strategi Penanggulangan-nya. Jurnal Litbang Pertanian, Volume 21 Nomor 1, Tahun 2002. Diunduh pada tanggal 08 Juli 2014 pukul 07.50 WIB dari http://scholar.google.co.id/scholar?q=i urnal+pengendalian+lalat+rumah\&btn $\mathrm{G}=$ \&hl=id\&as $\mathrm{sdt}=0 \% 2 \mathrm{C} 5$.

9. Sari, Mutiah, Lahmuddin Lubis, Yuswani Pangestiningsih. 2013. Uji Efektifitas Beberapa Insektisida Nabati untuk Mengendalikan Ulat Grayak (Spodoptera litura F.) (Lipodoptera:Noctuidae) di Laboratorium. Jurnal Online Agroekoteknologi Volume 1 Nomor 3, Juni 2013. Diunduh pada tanggal 2 Maret 2014 pukul 20.11 WIB dari http://scholar.google.co.id/scholar?q=j urnal+Insektisida+Nabati\&btnG=\&hl=i $\mathrm{d} \&$ as $\mathrm{sdt}=0 \% 2 \mathrm{C} 5$.

10. Sudarmo, Subiyakto. 2005. Teknologi Tepat Guna Pestisida Nabati, Pembuatan \& Pemanfaatannya. Yogyakarta: Kanisius. 